\title{
Lecture Room Design Towards the New Normal Pandemic Covid 19 (Lecture Room Case Study at UPN “Veteran” Jawa Timur)
}

\author{
Erwin Djuni*, Dyan Agustin, Annisa Izzati Firdaus \\ Architecture, Architecture and Design Faculty, Universitas Pembangunan Nasional "Veteran" Jawa Timur,
} Indonesia

*Corresponding author:

E-mail:

erwindw.ar@upnjatim.ac.id

\begin{abstract}
Classroom design management is very important for the continuity of the learning process, especially in a university. At the time of the current Covid 19 pandemic, the learning process has now turned online without using classrooms. But this certainly cannot go on continuously. The government has launched the New Normal program, which means that all activities are slowly being carried out again but with a maximum health protocol including the lecture learning process. The condition of the Covid 19 pandemic requires a lecture room design that can adapt to the needs of health protocols to break the chain of the spread of the virus. The purpose of this study is to analyze the types of activity in the lecture hall and the facilities needed so that a lecture room design can be obtained by the current conditions of the Covid 19 pandemic. The method used is qualitative deductive by describing the conditions of the lecture room and distributing questionnaires to students by filling out online questionnaires. The results of the study, in terms of seat arrangement according to the new normal, show that the type that can accommodate students the most is the rectangle type with an average capacity of $40 \%$ of normal capacity. Meanwhile, the design of the barrier between students is needed in the lecture hall to avoid droplets and to make it safer and more comfortable to attend lectures. In the existing door handle, an additional handle is designed so that it can open the door not by hand but my arm. Thus, it is hoped that the design of the new normal lecture room can break the chain of spreading covid 19.
\end{abstract}

Keywords: Design, lecture hall, new normal, covid 19

\section{Introduction}

The Covid 19 pandemic is an event that the coronavirus has spread around the world. The infection spreads through droplets from the respiratory tract when coughing or sneezing. This virus was first detected in the city of Wuhan in December 2019 and was designated a pandemic by the WHO. Covid 19 cases also exist in Indonesia and the number is increasing day by day. Until now, no vaccine has been found that can stop the spread of the virus. Various attempts have been made to break the chain of the spread of the Covid 19 virus, but this has also had an impact in all sectors, including in the education sector. The response taken in the world of education is the closure of schools and universities around the world, including in Indonesia (Nurkholis, 2020). Currently, the government requires students to study online and not go to campus. But this also will not continue because online learning also has weaknesses, among others, it requires an adequate internet network, costs a lot for quotas, and is slow (Windhiyana, 2020).

The Indonesian government is starting to prepare for a new phase called the new normal. New normal is a change in people's behavior to continue carrying out normal activities amid the Covid

\section{How to cite:}

Djuni, E., Agustin, D., \& Firdaus, A. I. (2021). Lecture room design towards the new normal pandemic covid 19 (lecture room case study at UPN “Veteran" Jawa Timur). $5^{\text {th }}$ International Seminar of Research Month 2020. NST Proceedings. pages 396-404. doi: 10.11594/ nstp.2021.0959 
19 pandemic while still implementing health protocols to prevent transmission. The main principle of the new normal is to stay active but maintain social distance and reduce physical contact with other people. This of course will also happen in the world of education, especially in universities. UPN Veteran East Java is one of the universities which is currently implementing online learning and eliminating campus lectures. This has started in March 2020 until now. In facing the preparation for the new normal, UPN veterans of East Java must prepare the learning process, especially the design of the lecture room properly and following health protocols. This of course requires an analysis of the physical condition of the current lecture hall so that later you can obtain an optimal lecture room design in terms of health, beauty, and comfort so that it will be able to support the teaching and learning process at the campus.

The purpose of this research is expected to find answers regarding the optimal arrangement of the lecture hall towards the new normal COVID-19 pandemic both in terms of physical facilities and the physical environment and in its development, it is hoped that it can be used as a guideline for government and other universities at the time of re-implementation of lectures in their respective campuses.

Furthermore, the researcher took the case of the UPN Veteran East Java campus as a state defense campus that represents a campus with several faculties that have different characters, including the Faculty of Architecture and Design (FAD) which represents the art field with lots of learning in studio lecture rooms and the Faculty of Business Economics (FEB). FISIP, Faculty of Law, Faculty of Agriculture, Faculty of Engineering which represents classrooms.

\section{Material and Methods}

This study uses a rationalistic approach with a qualitative deductive research method. The theory is applied to find problems in the field then make the research framework, process the data and results qualitatively. A rationalistic approach is an approach that sees the truth not solely from empirical facts but also through argumentation as a part of the thinking construction. The population is the total number of subjects or objects to be studied. The population in this study were lecturers and students of UPN Veteran East Java. The sample is a portion of the population that is considered representative of the population, given the limited funds and time, this study was conducted by sampling. The sample selection was made from several types of lecture rooms, including the theory lecture room and studio lecture room. Each lecture hall was taken from each faculty at UPN Veteran East Java, a sample of $30 \%$ was taken.

\section{Results and Discussion}

The lecture room is a space where face-to-face learning activities take place in the form of lectures, discussions, tutorials, seminars, and so on (Higher Education Facilities and Infrastructure standard, 2011). The maximum capacity of the room is 25 students with a standard space requirement of $2 \mathrm{~m} 2 /$ student. Circulation in the classroom is set at a minimum of $60 \mathrm{~cm}$ to facilitate movement. Each campus usually provides a large lecture hall with a capacity of 80 students and each student has a standard area of $1.5 \mathrm{~m} 2$ / student. The lecture room is equipped with facilities and infrastructure including lecturer chairs, student desks, LCD projectors, and a whiteboard.

The seating arrangement pattern in the classroom is divided into 5 types (Kumala \&Nur Hadiansyah, 2017):

a. Rectangle pattern

is a layered pattern facing forward that forms a square pattern. This pattern is widely used in learning spaces such as kindergarten, elementary, junior high, high school, and lecture classrooms. The activity that occurs in this pattern is a bit of discussion.

b. Semi circle pattern

The semi-circle pattern is a structured pattern that forms an arc facing forward. This pattern is usually used for the auditorium space. This pattern is for rooms with groups that need a little discussion. 
c. Horse-shoe pattern

The horseshoe pattern is a stacked pattern that travels from several of the same patterns facing forward. This pattern is usually used in workshop rooms and lecture rooms.

d. Conference pattern

A conference table pattern is a layered pattern with a circular shape with a reference point in the middle. This pattern is suitable for use in a meeting room or conference room. This pattern is for rooms with groups that require a lot of discussions.

e. Round tables pattern

A round table pattern is a pattern composed of the same patterns with several reference points. This kind of pattern is usually used in a studio room or room for internal activities.

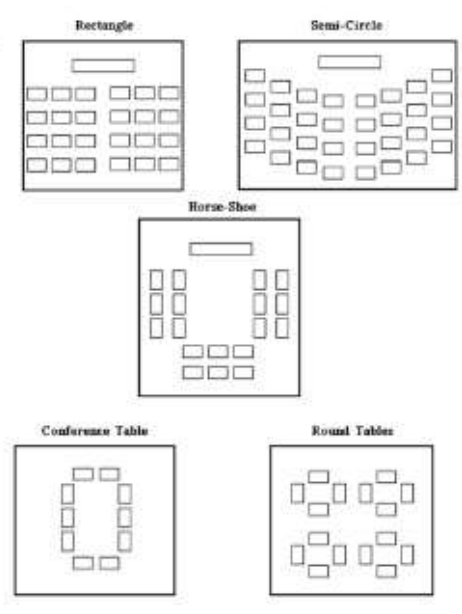

Figure 1. Classroom type based on sitting rules

\section{Data existing}

Based on the data obtained from observations at the location of the Theory Lecture Room and studios/laboratories in several faculties at UPN Veteran East Java, the results of the analysis are based on the elements forming the interior as follows:

a. Dimensions

Dimensions are associated with the scale or proportion with the ratio of the length, width, and height of the room and the number of users in the room. According to educational standards, a student requires a lecture space of $2 \mathrm{~m} 2$. In the observed lecture hall, the results showed that the proportion of the eight lecture halls and studios/labs in UPN was insufficient based on the comparison with the number of users. The average ceiling height of $3.2 \mathrm{~m}$ makes the room feel quite relieved. 
Table 1. Space dimension and capacity data

\begin{tabular}{llccc}
\hline No & \multicolumn{1}{c}{ Room Name } & Room Dimension & Space Area & Capacity \\
\hline \multirow{2}{*}{$\begin{array}{l}\text { Classroom Theory } \\
\text { R. Theory 3-1 }\end{array}$} & $10 \mathrm{~m} \times 7 \mathrm{~m}$ & 70 & 72 \\
2 & R.Theory 3-2 & $7 \mathrm{~m} \times 7 \mathrm{~m}$ & 49 & 68 \\
3 & Classroom 205 & $10 \mathrm{~m} \times 9 \mathrm{~m}$ & 90 & 50 \\
4 & R.Theory 4-1 & $10,5 \mathrm{~m} \times 8 \mathrm{~m}$ & 82 & 73 \\
& Lab/studio Room & $16 \mathrm{~m} \times 7 \mathrm{~m}$ & 112 & 80 \\
5 & R. Studio 4-1 & $10 \mathrm{~m} \times 9 \mathrm{~m}$ & 90 & 31 \\
6 & R.Smart \& Robotic Lab & $12 \mathrm{~m} \times 7 \mathrm{~m}$ & 84 & 24 \\
7 & R. Environment Lab & $7 \mathrm{~m} \times 7 \mathrm{~m}$ & 49 & 15 \\
8 & R.Graphic Computer Lab & & & \\
\hline
\end{tabular}

b. Form configuration

The form of configuration relates to the shape and arrangement of furniture. Almost all lecture halls observed at UPN Veteran East Java have a tiled pattern facing forward that forms a square pattern. This pattern is indeed the ablest to accommodate a large number of students but the nature of the activity is a little discussed.

Table2. The existing configuration type theory classroom

\begin{tabular}{ccc}
\hline No Room Name & Plan & $\begin{array}{c}\text { Configuration } \\
\text { Type }\end{array}$ \\
\hline
\end{tabular}

1 R. Theory 3-1

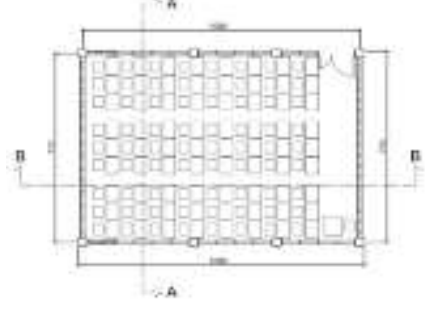

2 R.Theory $3-2$

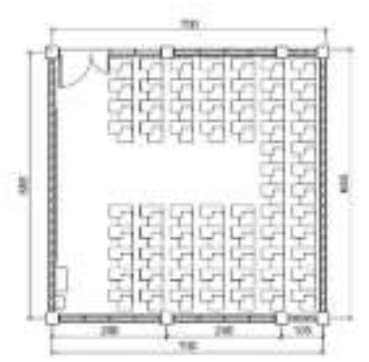

Rectangle

Rectangle

To be continued 
Room 205

R.Theory 4-1

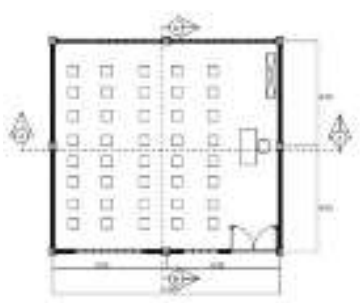

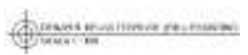

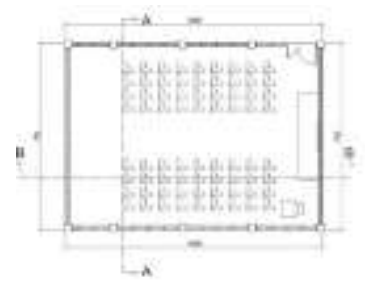

Rectangle

Rectangle

Whereas in the laboratory or studio room, more varied patterns appear, some are of the rectangle type and the round table type for discussion activities.

Table 3. The type of configuration for the existing Lab/Studio Classroom

No Room Name
$\begin{aligned} & \text { R.Studio 4-1 } \\ & \text { botic Lab }\end{aligned}$
$\begin{aligned} & \text { R. Environ- } \\ & \text { ment Lab }\end{aligned}$
$\begin{aligned} & \text { R.Graphic } \\ & \text { Computer Lab }\end{aligned}$




\section{The results of the lecture room analysis based on the health protocol}

When reopening schools, education officials can utilize a 7 step building risk management plan to assess hazards, prioritize and implement architectural and engineering (control) strategies and reduce risks. Its primary goal is to protect the health and safety of students, teachers, and staff while promoting a positive, friendly and safe learning environment.

Mitigation to reopen schools must address the following dangers:

1. Transmission of the virus through close contact (at least $1 \mathrm{~m}$ apart from other people if contact is more than 15 minutes) between teachers, staff, and students in large-scale face-to-face meetings such as classrooms and sports education activities. Close contact is the main way of transmitting covid so that it can be the focus of mitigation strategies.

2. Transmission of viruses from shared surfaces. All contact with surfaces that are touched by multiple persons should be considered, including (but not limited to) desks, labs, and gyms, equipment such as books, fountains, doorknobs, and personal items (for example, borrowing pencils, backpacks, and tools. electronic)

3. Aerosol transmission (possibly via HVAC system)

4. Fecal-oral transmission from sharing the same toilet

\section{a. Dimensions}

From the results of the analysis of the dimensions of the room with the capacity, it was found that the theoretical lecture room with the arrangement before pandemic almost $100 \%$ did not meet the requirements for a capacity of $2 \mathrm{~m} 2$ per student. The average capacity is only $1.2 \mathrm{~m} 2$ per student. This is due to maximizing space capacity. Meanwhile, the lab/studio lecture room still meets the requirements, namely more than $2 \mathrm{~m} 2$ per student. This is due to the factors of lab equipment and activities in each lab.

Table 4. Dimension to capacity comparison

\begin{tabular}{|c|c|c|c|c|c|c|}
\hline No & Room Name & $\begin{array}{l}\text { Room Dimen- } \\
\text { sions }\end{array}$ & $\begin{array}{l}\text { Space } \\
\text { Area }\end{array}$ & Capacity & $\begin{array}{c}\text { Proportion } \\
\left(2 m^{2}\right)\end{array}$ & Information \\
\hline & Ruang Kelas Teori & & & & & \\
\hline 1 & R. Theory 3-1 & $10 \mathrm{~m} \times 7 \mathrm{~m}$ & 70 & 72 & 0,97 & Not eligible \\
\hline 2 & R.Theory 3-2 & $7 \mathrm{~m} \times 7 \mathrm{~m}$ & 49 & 68 & 0,7 & Not eligible \\
\hline 3 & Clasroom 205 & $10 \mathrm{~m} \times 9 \mathrm{~m}$ & 90 & 50 & 1,8 & Not eligible \\
\hline 4 & $\begin{array}{l}\text { R.Theory 4-1 } \\
\text { Lab/studio }\end{array}$ & $10,5 \mathrm{~m} \times 8 \mathrm{~m}$ & 82 & 73 & 1,2 & Not eligible \\
\hline 5 & R,Studio 4-1 & $16 \mathrm{~m} \times 7 \mathrm{~m}$ & 112 & 80 & 1,4 & Not eligible \\
\hline 6 & $\begin{array}{l}\text { R.Smart \& Ro- } \\
\text { botic Lab }\end{array}$ & $10 \mathrm{~m} \times 9 \mathrm{~m}$ & 90 & 31 & 2,9 & Qualify \\
\hline 7 & $\begin{array}{l}\text { R. Environment } \\
\text { Lab }\end{array}$ & $12 \mathrm{~m} \times 7 \mathrm{~m}$ & 84 & 24 & 3,5 & Qualify \\
\hline 8 & $\begin{array}{l}\text { R. Graphic Com- } \\
\text { puter Lab }\end{array}$ & $7 \mathrm{~m} \times 7 \mathrm{~m}$ & 49 & 15 & 3,2 & Qualify \\
\hline
\end{tabular}

b. Design form configuration

In the form of a lecture chair and table arrangement configuration, several designs can be made following the health protocol rules 
Table 5. Dimension to capacity comparison

No Setup Type Name

\section{Picture}

1 Room Plan 3-1 Rectangle

type

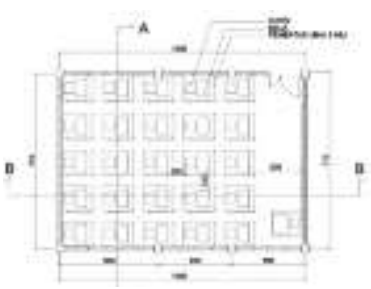

2 Room Plan 3-1 Semi Circle type

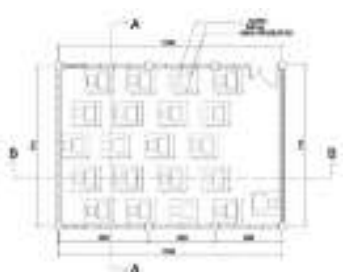

3 Room Plan 3-1Conference type

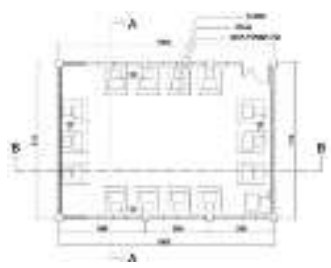

4 Room Plan 3-1 Horse Shoe type

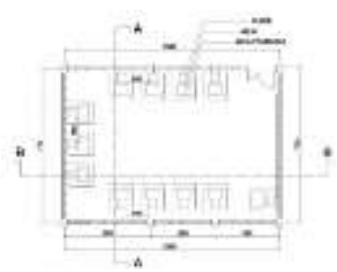

5 Room Plan 3-1 Round Table type

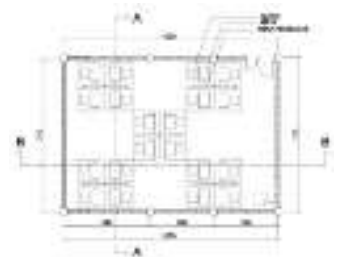


Table 6. Analysis of student capacity based on seat change type for the theory lecture hall

\section{College Student Capacity}

\begin{tabular}{|c|c|c|c|c|c|c|c|c|c|c|c|c|}
\hline \multirow[t]{2}{*}{ No } & \multirow[t]{2}{*}{$\begin{array}{l}\text { Room } \\
\text { Name }\end{array}$} & \multirow{2}{*}{$\begin{array}{c}\text { Initial } \\
\text { amount }\end{array}$} & \multicolumn{2}{|c|}{$\begin{array}{l}\text { Rectangle } \\
\text { Type }\end{array}$} & \multicolumn{2}{|c|}{$\begin{array}{c}\text { Semi Circle } \\
\text { Type }\end{array}$} & \multicolumn{2}{|c|}{$\begin{array}{c}\text { Shoe Horse } \\
\text { Type }\end{array}$} & \multicolumn{2}{|c|}{$\begin{array}{c}\text { Conference } \\
\text { Type }\end{array}$} & \multicolumn{2}{|c|}{$\begin{array}{c}\text { Round Ta- } \\
\text { ble Type }\end{array}$} \\
\hline & & & Intl & $\%$ & Intl & $\%$ & Intl & $\%$ & Intl & $\%$ & Intl & $\%$ \\
\hline 1 & $\begin{array}{l}\text { Theory } \\
\text { 3-1 FAD }\end{array}$ & 72 & 25 & $35 \%$ & 20 & $28 \%$ & 11 & $15 \%$ & 14 & $19 \%$ & 20 & $28 \%$ \\
\hline 2 & $\begin{array}{l}\text { Theory } \\
\text { 3-2 FAD }\end{array}$ & 69 & 20 & $29 \%$ & 15 & $21 \%$ & 9 & $13 \%$ & 10 & $15 \%$ & 16 & $23 \%$ \\
\hline 3 & $\begin{array}{l}\text { Theory } \\
205 \text { FIK }\end{array}$ & 50 & 20 & $40 \%$ & 20 & $40 \%$ & 20 & $40 \%$ & 20 & $40 \%$ & 20 & $40 \%$ \\
\hline 4 & $\begin{array}{l}\text { Theory } \\
\text { 4-1 FT }\end{array}$ & 56 & 30 & $54 \%$ & 25 & $45 \%$ & 11 & $20 \%$ & 14 & $25 \%$ & 20 & $36 \%$ \\
\hline 5 & $\begin{array}{l}\text { Studio } \\
\text { 4-1 FAD }\end{array}$ & 72 & 20 & $28 \%$ & 12 & $17 \%$ & 16 & $23 \%$ & 12 & $17 \%$ & 12 & $17 \%$ \\
\hline & average & & & $40 \%$ & & $30 \%$ & & $23 \%$ & & $23 \%$ & & $29 \%$ \\
\hline
\end{tabular}

Table 7. Analysis of student capacity based on change of seat type for lecture hall Lab/studio

\begin{tabular}{|c|c|c|c|c|c|c|c|c|c|c|c|c|}
\hline \multirow{3}{*}{ No } & \multirow{3}{*}{$\begin{array}{l}\text { Room } \\
\text { Name }\end{array}$} & \multicolumn{11}{|c|}{ Capacity Number of Student } \\
\hline & & \multirow{2}{*}{$\begin{array}{c}\text { Initial } \\
\text { amount }\end{array}$} & \multicolumn{2}{|c|}{$\begin{array}{l}\text { Rectangle } \\
\text { Type }\end{array}$} & \multicolumn{2}{|c|}{$\begin{array}{c}\text { Semi Circle } \\
\text { Type }\end{array}$} & \multicolumn{2}{|c|}{$\begin{array}{c}\text { Shoe Horse } \\
\text { Type }\end{array}$} & \multicolumn{2}{|c|}{$\begin{array}{c}\text { Confer- } \\
\text { ence Type }\end{array}$} & \multicolumn{2}{|c|}{$\begin{array}{l}\text { Round Ta } \\
\text { ble Type }\end{array}$} \\
\hline & & & Intl & $\%$ & Intl & $\%$ & Intl & $\%$ & Intl & $\%$ & Intl & $\%$ \\
\hline 1 & $\begin{array}{l}\text { Smart Lab } \\
\text { FIK }\end{array}$ & 15 & 15 & 100 & - & - & - & - & - & - & - & - \\
\hline
\end{tabular}




\begin{tabular}{|c|c|c|c|c|c|c|c|c|c|c|c|c|}
\hline 2 & $\begin{array}{l}\text { Environ- } \\
\text { ment Lab } \\
\text { FT }\end{array}$ & 24 & - & - & - & - & - & - & - & - & 12 & 50 \\
\hline 3 & $\begin{array}{l}\text { Lab } \\
\text { Komgraf } \\
\text { FAD }\end{array}$ & 15 & 8 & 53 & - & - & - & - & - & - & - & - \\
\hline
\end{tabular}

\section{Conclusion}

From the analysis above, changes in the shape of the room configuration are influenced by the following:
a. Dimensions
The wider the room, the easier it will be to change the shape of the seating configuration
b. Design Form Configuration
In the Theory Lecture Room, the rectangle type accommodates the student capacity as much as $40 \%$. In the lab/studio room, the position of furniture cannot be changed due to the activity and area of the furniture but can provide a dividing partition between the seats.

\section{Acknowledgment}

Universitas Pembangunan Nasional "Veteran" Jawa Timur for the support in this research through SKIM RISDA 2020. Hopefully, the results of this research can be useful for UPN Veteran East Java in particular and society in general.

\section{References}

BSNP. (2011). Standard design for postgraduate and professional higher education facilities and infrastructure. Jakarta: BSNP Kumala M. D., \& Nur Hadiansyah, M. (2017). Analysis of distance and perspective of sitting position in lecture room against student learning effectiveness in Tokong Nanas Building, Telkom University. Idealogi: Indonesian Design Ideas and Dialogue, 1(2), 146.

Nurkholis. (2020). the impact of the pandemic novel corona virus disiase (Covid 19) on psychology and education and government policy. PGSD Journal, 6(1), 1-10.

Windhiyana E. (2020). The impact of covid 19 on online learning activities in a Kisten College in Indonesia. Journal of PERSPEKTIF IImu Pendidikan, 34(1), 1-7. 